\title{
Prednisone for the Treatment of Acute Nonspecific Mesenteric Lymphadenitis
}

\author{
Momcilo Pavlovic ${ }^{1 *}$, Zeljko Rokvic ${ }^{2}$, Karolina Berenji ${ }^{3}$ \\ ${ }^{1}$ Children's Ambulatory Care Center Subotica, Serbia; ${ }^{2}$ Department of Diagnostic Imaging, General Hospital Subotica, Serbia; \\ ${ }^{3}$ Department of Hygiene and Human Ecology, Public Health Institute, Subotica, Serbia
}

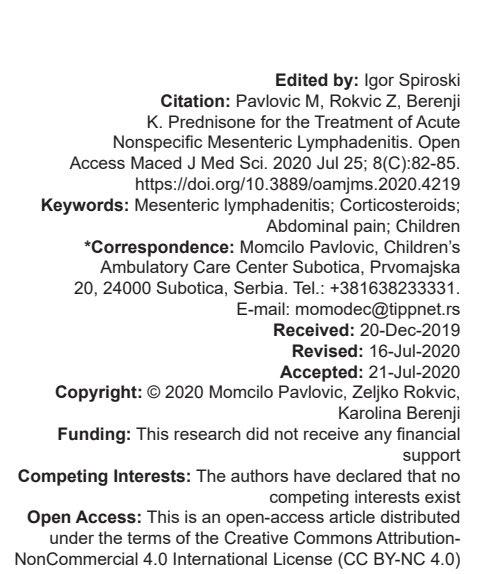

\section{Introduction}

Primary or acute nonspecific mesenteric lymphadenitis (ANML) is a recognized and well-known cause of acute abdominal pain in children. However, diagnosis of this self-limiting condition is not always straightforward due to the age of the child, lack of specific signs, and common diagnostic criteria [1], [2]. An underlying viral infection (adenovirus, herpes simplex, influenza virus) is thought to be the cause in most cases of ANML. Meanwhile other reported causes of mesenteric lymphadenitis (or secondary) include bacterial (yersiniosis, salmonellosis, and tubercle bacilli), tumor mesenteric lymphadenitis (lymphoma and acute leukemia), parasitic, autoimmune diseases, as well as immunodeficiencies [3]. In clinical practice, these conditions are medical rarities, and the most common dilemma is distinguishing appendiceal inflammation from that of ANML [4]. All children with ANML presented with abdominal pain, whereas other characteristic symptoms include fever, nausea, vomiting, diarrhea, constipation, and anorexia, accompanied with normal or mild elevated markers of inflammatory conditions [4], [5].

In addition to the fact that ANML has no effective therapy, the supportive treatment and time-intensive "wait and see" approach often becomes discouraging for both patients and their families. Against this backdrop, the goal of the current study was to evaluate the efficacy of oral prednisone for pain relief in children with ANML.

\section{Case Report}

Seven patients (three boys and four girls) who presented in the Children's Ambulatory Care Center Subotica between September 2018 and May 2019 with ANML were prospectively analyzed. The average patient age was 8.2 years (range: 5.3-13.7 years). All patients provided a clinical history after which a complete physical examination was performed by pediatrician gastroenterologist and pediatric surgeon. The diagnosis of ANML in children was made in accordance (a) characteristic signs and symptoms; (b) an abdominal ultrasound demonstrating enlarged three or more lymph nodes, short-axis diameter of 8 $\mathrm{mm}$ or more in at least one of them (Figure 1); and (c) laboratory and ultrasound exclusion of appendicitis along with other causes of abdominal pain [4], [5]. 
The ethical board at our center gave its approval to the study and all parents gave written consent. The patients subjectively evaluated the intensity of the pain using numeric rating scale (NRS) with numbers ranging from 0 to 10 with 0 denoting "no pain" and 10 representing "worst possible pain" as the endpoints [6]. It is notable that we only included patients with pain scores above 6/10 in the study. Pain scores below 4/10 were considered as a satisfactory therapeutic response. Six patients had vomiting (85.7\%), five anorexia $(71.4 \%)$, four fever $(57.4 \%)$, and one diarrhea $(14.2 \%)$ and constipation $(14.2 \%)$. Laboratory tests (complete blood cell count, C-reactive protein-CRP, amylase, liver function tests, urea, creatinine, urinalysis, stool parasite analysis, and stool culture) were found to be normal. During episodes of pain, we recommended acetaminophen for analgesia. Following the exclusion of other diseases, patients were treated with oral prednisone $1 \mathrm{mg} / \mathrm{kg}$ (maximum $40 \mathrm{mg}$ ) once daily for between 2 and 5 days. The last dose of prednisone was received by patients 1 day after NRS score was found to be below 4/10.

The characteristics of abdominal pain in our children are depicted in Table 1.

All other pre-existing signs and symptoms were found to disappear during the corticosteroid therapy. Even adverse effects of corticosteroids did not show up. Two patients were examined on control ultrasound 1 month after inclusion in the study, whereas mesenterial lymph nodes were normal.

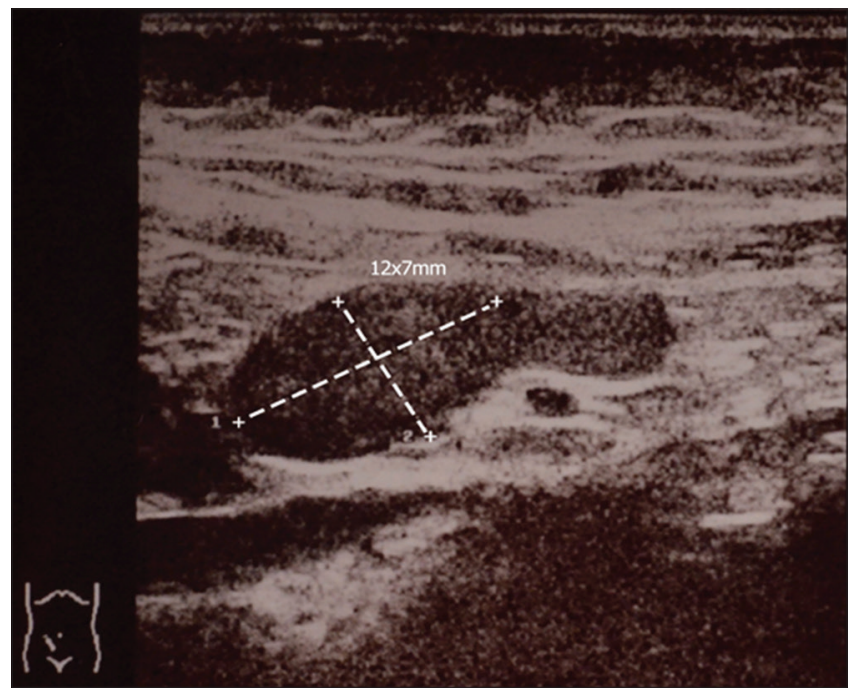

Figure 1: Mesenteric lymph node enlargement on abdominal ultrasound in a 7-year-old girl with acute nonspecific mesenteric lymphadenitis

\section{Discussion}

As stated before, ANML is a self-limiting disease with mostly no specific cure. The treatment overlaps with many pain syndromes and includes bed rest, hydration (infusion therapy based on the indications), and acetaminophen or a non-steroidal antiinflammatory agent [7]. To the best of our knowledge, this marks the first attempt to treat ANML with corticosteroids. We searched for the articles published in PubMed, Embase, and Cochrane Library until the month of May 2019 with no language restrictions using the following keywords: "Acute nonspecific mesenteric lymphadenitis," "mesenteric lymphadenitis," and "treatment" or "corticosteroids."

Corticosteroid therapy has been found to be beneficial in some viral infections alone, or as adjuvants with active antimicrobial agents in many infectious diseases [8]. Short-term corticosteroid therapy reduces acute inflammation by inhibiting the activation of inflammatory cells. In addition, it lowers the pain in acute sinusitis as well as upper respiratory tract infections [9]. Studies in adults and children reveal that a single dose of oral dexamethasone in combination with antibiotics increased the likelihood of resolution and improvement of pain in patients with a severe streptococcal sore throat [10]. Correspondingly, Roy et al. found that oral dexamethasone, $0.3 \mathrm{mg} / \mathrm{kg}$ for 7 days is effective for pain relief in acute exudative pharyngitis among children with suspected infectious mononucleosis [11]. However, reports pertaining to the effectiveness of corticosteroids for control of swollen lymph glands in mononucleosis are conflicting [12]. Meanwhile corticosteroids do reduce post-operative pain in children and facilitate the prevention of postoperative nausea and vomiting [13].

The controversy is attributed to the potential benefits and adverse events of short-course therapy of corticosteroids in self-limiting diseases such as ANML. At times, health-care providers are reluctant to prescribe corticosteroids due to their immunosuppressive tendencies and potential side effects. However, reports of these side effects during short-course corticosteroid therapy are anecdotal and largely self-limiting (peritonsillar abscess, encephalitis, and myocarditis) [12], [14]. To that end, it is noteworthy that we did not observe any side effects induced by corticosteroid in our patients.

Table 1: Characteristics of abdominal pain in seven patients affected with acute nonspecific mesenteric lymphadenitis

\begin{tabular}{|c|c|c|c|c|c|c|c|}
\hline Case number & $\begin{array}{l}\text { Localization of abdominal } \\
\text { pain }\end{array}$ & $\begin{array}{l}\text { Nocturnal } \\
\text { abdominal pain }\end{array}$ & $\begin{array}{l}\text { Duration of pain before } \\
\text { treatment (days) }\end{array}$ & $\begin{array}{l}\text { Duration of pain after } \\
\text { start of treatment (days) }\end{array}$ & $\begin{array}{l}\text { Pain intensity before } \\
\text { treatment }(1-10)\end{array}$ & $\begin{array}{l}\text { Pain intensity after } \\
\text { treatment }(1-10)\end{array}$ & $\begin{array}{l}\text { Reduction from baseline } \\
\text { pain difference }(\%)\end{array}$ \\
\hline 1 & lleocecal & Yes & 6 & 1 & 9 & 0 & $9(100)$ \\
\hline 2 & Periumbilical & No & 7 & 2 & 8 & 1 & $7(87.5)$ \\
\hline 3 & Periumbilical & No & 6 & 1 & 8 & 0 & $8(100)$ \\
\hline 4 & Periumbilical & No & 14 & 4 & 7 & 2 & $5(71.4)$ \\
\hline 5 & Periumbilical & Yes & 3 & 1 & 8 & 0 & $8(100)$ \\
\hline 6 & Ileocecal and periumbilical & No & 3 & 2 & 8 & 2 & $6(75)$ \\
\hline 7 & Ileocecal & Yes & 6 & 1 & 10 & 0 & $10(100)$ \\
\hline Mean & & & 6.4 & 1.7 & 8.2 & 0.7 & $7.5(85.3)$ \\
\hline
\end{tabular}


In ANML, children commonly recover within 2-3 weeks, although symptoms persist for 3-10 weeks in half of the patients [7], [15]. Meantime of abdominal pain before therapy in our patients was less than a week; however, the recovery time after treating with prednisone was 1.7 days. We were guided by recommendations of European Society for Paediatric Anaesthesiology that the target should be to achieve and maintain pain scores below the intervention threshold of 4 (on a 10-point scale) [16]. Clinically important differences in acute pain relief using patients' perception have an impact on which analgesic interventions are regarded useful. The minimum clinically important pain reductions before and after the interventions have varied greatly between studies, with relative difference ranging from $13 \%$ to $85 \%$ [17]. In our study, the relative difference is $85.3 \%$, which is a large decrease to perceive relief. In addition, we can assume that the resolution of pain and other disturbances can prevent dehydration and obviate the need for infusion therapy.

Notably, we did not use prednisone for all children with ANML in our center, nor do we support their routine use in ANML. We believe that corticosteroid therapy is only needed in severe forms of abdominal pain.

Since research on this subject is extremely limited, more placebo-controlled studies with greater number of patients are necessitated to confirm these findings.

\section{Conclusion}

Pain control should be a therapeutic goal in patients with ANML. In this regard, prednisone, as adjuvant therapy in conjunction with analgesics, is an adequate and safe therapy, especially in severe forms of this disease.

\section{References}

1. Corper FJ. Acute mesenteric lymphadenitis in childhood. Q Bull Northwest Univ Med Sch. 1951;25(3):279-81. PMid:14864838

2. Karmazyn B, Werner EA, Rejaie B, Applegate KE. Mesenteric lymph nodes in children: What is normal? Pediatr Radiol. 2005;35(8):774-77. https://doi.org/10.1007/s00247-005-1462-2 PMid:15883829

3. Lee JH, Rhee PL, Lee JK, Son HJ, Kim JJ, Koh KC, et al. The etiology and clinical characteristics of mesenteric adenitis in Korean adults. J Korean Med Sci. 1997;12(2):105-10. PMid:9170014
4. Toorenvliet B, Vellekoop A, Bakker R, Wiersma F, Mertens B, Merkus $\mathrm{J}$, et al. Clinical differentiation between acute appendicitis and acute mesenteric lymphadenitis in children. Eur J Pediatr Surg. 2011;21(2):120-3. https://doi.org/10.3346/ jkms.1997.12.2.105 PMid:21157689

5. Gross I, Siedner-Weintraub Y, Stibbe S, Rekhtman D, Weiss D, Simanovsky N, et al. Characteristics of mesenteric lymphadenitis in comparison with those of acute appendicitis in children. Eur J Pediatr. 2017;176(2):199-205. https://doi. org/10.1055/s-0030-1267979

PMid:27987102

6. Breivik $H$, Borchgrevink PC, Allen SM, Rosseland LA, Romundstad L, Hals EK, et al. Assessment of pain. $\mathrm{Br} J$ Anaesth. 2008;101(1):17-24.

PMid: 18487245

7. Helbling $R$, Conficconi $E$, Wyttenbach $M$, Benetti $C$, Simonetti GD, Bianchetti MG, et al. Acute nonspecific mesenteric lymphadenitis: More than no need for surgery. Biomed Res Int. 2017;2017:9784565. https://doi.org/10.1007/ s00431-016-2822-7

PMid:28261620

8. McGee S, Hirschmann J. Use of corticosteroids in treating infectious diseases. Arch Intern Med. 2008;168(10):1034-46.

PMid:18504331

9. Fernandes RM, Oleszczuk M, Woods CR, Rowe BH, Cates CJ, Hartling L. The Cochrane Library and safety of systemic corticosteroids for acute respiratory conditions in children: An overview of reviews. Evid Based Child Health. 2014;9(3):73347. https://doi.org/10.1155/2017/9784565 PMid:25236311

10. Schams SC, Goldman RD. Steroids as adjuvant treatment of sore throat in acute bacterial pharyngitis. Can Fam Physician. 2012;58(1):52-4. https://doi.org/10.1001/ archinte.168.10.1034

PMid:22267621

11. Roy M, Bailey B, Amre DK, Girodias JB, Bussières JF, Gaudreault P. Dexamethasone for the treatment of sore throat in children with suspected infectious mononucleosis: A randomized, double-blind, placebo-controlled, clinical trial. Arch Pediatr Adolesc Med. 2004;158(3):250-4.

PMid:14993084

12. Rezk E, Nofal YH, Hamzeh A, Aboujaib MF, AlKheder MA, Al Hammad MF. Steroids for symptom control in infectious mononucleosis. Cochrane Database Syst Rev. 2015;11(1):CD004402. https://doi.org/10.1002/ebch.1980 PMid:26558642

13. Shirazi M, Mahmoudi $H$, Nasihatkon B, Ghaffaripour S, Eslahi A Efficacy of dexamethasone on postoperative analgesia in children undergoing hypospadias repair. Pak J Med Sci. 2016;32(1):125-9. PMid:27022359

14. Andersson J, Ernberg I. Management of Epstein-Barr virus infections. Am J Med. 1988;85(2A):107-15. PMid:2841854

15. Benetti C, Conficconi E, Hamitaga F, Wyttenbach M, Lava SA, Milani GP, et al. Course of acute nonspecific mesenteric lymphadenitis: Single-center experience. Eur J Pediatr. 2018;177(2):243-6. https://doi.org/10.1001/ archpedi.158.3.250

PMid:28913615

16. Vittinghoff $M$, Lönnqvist PA, Mossetti $V$, Heschl S, Simic D, Colovic $\mathrm{V}$, et al. Postoperative pain management in children: Guidance from the pain committee of the European society for 
paediatric anaesthesiology (ESPA pain management ladder initiative). Paediatr Anaesth. 2018;28(6):493-506.

17. Olsen MF, Bjerre E, Hansen MD, Hilden J, Landler NE, Tendal B, et al. Pain relief that matters to patients: Systematic review of empirical studies assessing the minimum clinically important difference in acute pain. BMC Med. 2017;15(1):35. https://doi. org/10.1002/14651858.cd004402.pub3

PMid:28215182 